\title{
SAVINGS FOR RETIREMENT AND THE MILLENNIAL GENERATION IN MEXICO: PERCEPTION ABOUT THE IMPORTANCE OF HAVING A RETIREMENT FUND
}

\author{
Teresa Zamora-Lobato \\ Instituto Tecnológico Superior de Misantla \\ maría.jz@misantla.tecnm.mx
}

Recepción Artículo: 12 marzo 2021

Admisión Evaluación: 15 marzo 2021

Informe Evaluador 1: 18 marzo 2021

Informe Evaluador 2: 20 marzo 2021

Aprobación Publicación: 22 marzo 2021

\begin{abstract}
The aim of this study focused on knowing the existing relation between Savings, Financial Capability, Future forecast and Retirement funds in relation to gender, which allows to determine the Savings culture, while also proving if there is a relationship between Savings, Financial Capability, Future forecast and Retirement funds in relation to gender among the population known as Millennial generation. The study is non-experimental, approached from the hypothetic-deductive paradigm, it is descriptive and correlational, as well as transversallycut. The participants were 89 Millennials ( $73 \%$ women and 27\% men), whose ages ranged between 18 to 35 years old. The sample was non-probabilistic by auto-determination, since the technique used was "snowball sampling", which consisted on sharing the instrument through social networks. For the study, the survey designed by the Mexican National Commission of Retirement Savings System (2017) was used. For the data capture and analysis, the program SPSS Statistics v23 was used and the measurement technique was Pearson s Chi square with $d f$ and sig $<0.05$. The main results show how young millennials have not thought about retirement or at least, they are currently not taking action on this issue, hence, they have not decided to save money for the future at the moment. Regarding the parametric results, it was determined that there is no relationship between what millennials perceive about keeping a record of monthly income and expenses, what they would do in case they received an unexpected sum of money, receive a monthly pension, the retirement age, amount of the retirement pension and the knowledge of what a retirement fund is with the variable gender.
\end{abstract}

Keywords: millennials; retirement savings and financial culture; JEL: D1, E21, J14, D91

\section{RESUMEN}

Ahorro para la jubilación y generación millennial en México: percepción sobre la importancia de tener un fondo de jubilación. La investigación, se centró en conocer la relación existente entre Ahorro, Capacidad Financiera, Proyección de Futuro y Fondos de Jubilación en relación al género, permitiendo 
determinar la cultura del Ahorro, además de comprobar si existe relación entre la población conocida como generación Millennial. El estudio es no experimental, abordado desde el paradigma hipotético-deductivo, es descriptivo y correlacional, así como de corte transversal. La muestra fue no probabilística por autodeterminación, ya que la técnica utilizada fue el "muestreo de bola de nieve", que consistió en compartir el instrumento a través de las redes sociales. Se utilizó la encuesta diseñada por la Comisión Nacional del Sistema de Ahorro para el Retiro de México (2017). Para la captura y análisis de datos se utilizó el programa SPSS Statistics v23 y la técnica de medición fue Chi cuadrado de Pearson con gl y sig <0.05. Los principales resultados muestran cómo los jóvenes millennials no han pensado en la jubilación o al menos, actualmente no están tomando medidas sobre este tema, por lo que no han decidido ahorrar dinero para el futuro en este momento. En cuanto a los resultados paramétricos, se determinó que no existe relación entre lo que perciben los millennials acerca de llevar un registro de ingresos y gastos mensuales, lo que harían en caso de recibir una suma inesperada de dinero, recibir una pensión mensual, la edad de jubilación, monto de la pensión de jubilación y el conocimiento de qué es un fondo de jubilación con la variable género.

Palabras clave: millennials; ahorro para la jubilación y cultura financiera; JEL: D1, E21, J14, D91

\section{INTRODUCTION}

Millennials are those people between the ages of 18 to 35 years old, a population of 24 million people in the country of Mexico (INEGI, 2015). Nowadays it is important to create awareness in this young people in order for them to acquire a savings culture, because this generation is not paying as much attention to the issue of retirement as they should and they prefer to place more importance in the present than in the future (Mexican National Commission of Retirement Savings System - CONSAR, 2017).

According to Zamora-Lobato, García-Santillán \& Ramos-Hernández (2018), saving money is one of the most important aspects in the economic life of people, allowing to attain economic safety as well, and one of the objectives of saving is retirement planning.

From the beginning, there has been concern about whether young people have been saving money for retirement. The topic of saving is currently fundamental, but unfortunately, financial education levels are insufficient.

In the United States, this fact was starting to be observed since the Baby Boomers generation, who according to Bernheim (1993) were not prepared for retirement. Furthermore, Yao \& Cheng (2017) state that today, young people from the USA are not saving money despite the benefits they could obtain if they did so.

Conversely, in European countries, this issue is less concerning: for example, in the United Kingdom, people receive financial orientation since childhood in order to make them aware and start to value the need of saving for their retirement in the future (Rolison et al., 2017). Similarly, Johnson (2016) considers that in Asia people have a great saving culture since these people save $41.5 \%$ of their income, the highest saving percentage worldwide. On the contrary, according to this author, in Latin America people save $17.6 \%$ of their income, only a little higher than the lowest percentage, which is $13.7 \%$.

Regrettably, the case of Mexico is no exception. In Mexico, the is no saving culture due to the lack of interest and the scarce financial education and knowledge of this subject in the country. Mexico has one of the lowest levels of education compared to other nations in Latin America (García, Grifoni, López \& Mejía, 2013).

The National Saving and Financial Services Bank (BANSEFI, 2015) points out that governments must encourage financial culture, while developing the necessary abilities to make informed decisions, that is, seeking a correct management of earnings and expenses in order to have a better quality of life during retirement (Alvarado et al., 2018).

Continuing with these authors, they mention how, fortunately, this generation has great opportunities to deal with such an important challenge, which is one of the greatest they will face in life. Despite the lack of a saving culture in Mexico, these young people have higher education levels than previous generations and adapt easily to changes. 
In this context, empiric evidence is analyzed and discussed, as well as the theoretical approaches to explain the studied phenomenon. Hence, from the stated arguments arises the following question: in the population called Millennial generation, what is the existing relationship between Saving, Financial Capability, Future forecast and Retirement funds in relation to gender in order to determine a saving culture?

For this study, it is analyzed if there is a relationship between Saving, Financial Capability, Future forecast and Retirement funds in relation to gender among the population called Millennial generation. For said reason, we seek to know the opinion of Millennials about Saving, Financial Capability, Future forecast and Retirement funds.

\section{LITERATURE REVIEW}

The topic of saving has been studied previously, however, the analysis about the behavior and motivations of saving are few. The former justifies this study and it is the reason why this research project on such an important issue nowadays is of interest, hoping it is useful in promoting a saving culture and proving awareness in young Millennials so they do not postpone this issue. Therefore, the relevance of this research lies in the consequences that not promptly having a saving plan can have in the future.

Considering that the object of study is saving, this work aligns with the purpose of Keynes s theory (1936) about saving, which, since its origins, explains how individuals only make saving decisions motivated by the present and never consider a future horizon or foresight, meaning that people prefer spending to saving, as it happens with this generation in the present.

For Keynes, saving refers to the surplus of a person s income without taxes. One of the main advantages is how saving money allows to pay for future expenses, that is, part of the income should be destined to consumption and the rest is what must be saved. It should be taken into account that savings depend on rent, so saving is contingent on the later as the higher rent is, the higher savings will be and the economic growth will be higher as well, which can create a virtuous circle.

Regarding retirement saving and financial behavior of Millennials, there are studies providing an explanation on the subject, for example, the Mexican National Commission of Retirement Savings System (2007) carried out a survey revealing that one of the reasons why Millennials show no interest and do not save money for retirement is because they have a vision of job retirement as being nonchalantly faraway, given how only $20 \%$ considers saving to be important.

The National Bank of Mexico and the National Autonomous University of Mexico agree with the former since a study done by these two institutions shows how most young people do not save any money because they do not consider retirement to be of concern. Similarly, $61 \%$ of so-called Millennials declare they have NEVER thought about saving for retirement during their job life (Banamex-UNAM, 2014).

Additionally, other reason why there is a lack of interest for this subject in Mexico is due to the fact that this generation prefers to spend money in technology and entertainment, among other things, rather than saving it according to Wealth Planters (2017). Young people give more importance to consume "now" than in the "future" and even consume beyond their means (Finke \& Huston, 2013).

Coupled with this, the lack of a saving habit is also directly related to the low level of received income, inflation, unemployment, socio-economic level and geographic zone, as mentioned by Calderón \& Gaytán (2017). This is concerning because if Millennials keep this up and do not start to save since they begin to work, there will be consequences in the future since the current pension system is not favorable; just like in the USA, the problem lies in the return rates, which are very low for the current economy, as mentioned by Bams, Schotman, \& Tyagi (2016). In Mexico, the Retirement Savings System Contribution Rates rank in the last position among the countries in the Organization for Economic Cooperation and Development (OECD, 2016).

Continuing with this subject, this organization indicates that the contributions to the system are too small to ensure pension benefits of over $50 \%$ of the final income. According to the calculations made by this entity, a contribution rate of $6.5 \%$, in the best of cases, would achieve a replacement rate of barely $26 \%$ for the Millennial employee. 
Likewise, Rivera \& Nava (2012), determine that the amount received as retirement is less than half of the last earned income, so it directly affects the wellbeing of retired people and their families, which is why this system is not designed to be the only sustenance, as it will not be enough and will have to be complemented with voluntary contributions. Vázquez (2010) agrees with this statement, mentioning how, on average, the current pensions for an IMSS retired are worth \$2 000 MXN, while for an ISSSTE retired they are worth $\$ 7000$ MXN.

Nonetheless, the OECD remarks the possibility of achieving an increase in the pension payment by increasing the replacement rate $50 \%$, making contributions of 13 to $18 \%$ of the income during 40 years and starting to do so since one begins to work, in order to be able to retire at a reasonable age; if Millennials fail to do this they will be retiring when they are 70 years old, as stated by the CONSAR (2017).

The former is the reason why Millennials have to assume more responsibilities to prepare themselves financially for retirement. It is fundamental that young people start to save and invest for retirement at the beginning of their careers. Thereby, strategic and disciplined saving will help achieve a good economy when they retire (Yao \& Cheng, 2017).

\section{METHODOLOGY}

The question of this research is the following: what is the existing relationship between Saving, Financial Capability, Future forecast and Retirement funds in relation to gender in order to determine a saving culture? Specifically, in the population called Millennial generation. This study is approached from the hypothetic-deductive paradigm, because from the obtained results it will be possible to make inferences to achieve the results set in the aim of this study. Thus, this study is non-experimental as it does not seek to manipulate the independent variables $(X)$ to modify their effects $(Y)$.

For Heman (2017), Millennials are those people who were born approximately in the last two decades of the $20^{\text {th }}$ Century. They are people who highlight the importance of current issues and challenges, while showing less interest in personal development, as is the case with their lack of education related to the practice of saving money (Goldman Sachs, 2016).

Saving is the process through which an economic entity reserves part of its product and uses it to generate income in the future, while future forecast refers to a way of anticipating the future and prepare (Huidobro, 1995). Saving is considered as an anticipatory mechanism for retirement and old age (Vázquez-Parra, Montalvo-Corzo, Amézquita- Zamora \& Arredondo-Trapero, 2017).

Alternatively, Escalera-Chávez, Tejada-Peña \& García-Santillán (2017) define Financial Capability as the knowledge, financial abilities and access to financial services that allow people to understand and act in their best economic interest.

Lastly, according to article 18 of the Retirement Saving Systems Law, retirement funds are defined as financial entities which are exclusively, regularly and professionally dedicated to manage individual accounts and channel the resources from the sub-accounts that made them up in accordance to the laws on social security (Law 077 , 2014, art. 18).

The kind of study used in this research starts as descriptive, where all the frequencies obtained by each of the indicators of the used instrument are described and is correlational too, as it aims to determine the relationship between the involved variables and gender. Also, due to the fact that the information was obtained at a single moment, the empiric study is transversally cut.

The key informers of this study are Millennial young people between the ages of 18 and 35 years old, whose group is among those directly benefiting from the pension payment. We aim to gather information leading to the answer of the research question and so, a percentage of young people in the conurbation area of Veracruz-Boca del Rio were selected.

For this research, the sample was non-probabilistic and purposing; the technique of snowball sampling was applied, which consisted on sharing the instrument (more details next) through social networks so the followers 
of the ones doing the study could answer it, as well as their contacts in order to reach more people. The total number of people surveyed by this instrument were 89 .

The survey used in this study was designed by the Mexican National Commission of Retirement Savings System (2017). To carry out this study, the questions that were considered pertinent were used in accordance with the variables of the research. The questionnaire was divided in the following four topics: saving concept, financial capabilities, future forecast / pension and retirement funds.

The application and gathering of information from the survey applied to young Millennials was done using the tool Google forms. The design of surveys and obtention of information through internet is done in a simple manner, as well as the application, since it can be answered from a cellphone. Once the surveys are applied and the information has been gathered, the database was loaded to the software IBM SPSS Statistics v23 to proceed to the data analysis.

To contrast the hypothesis, the statistic Chi square Pearson test with $d f$ and significance $(<0.05)$ was used. The decision criteria are: if table $\mathrm{Chi}^{2}$ is $>$ than calculated $\mathrm{Chi}^{2}$ then $\mathrm{HO}$ is not rejected; on the contrary if table $\mathrm{Chi}^{2}$ is $<$ than calculated $\mathrm{Chi}^{2} \mathrm{HO}$ is rejected. Also, if the statistical significance is $<0.05$, it supports the statistic $\mathrm{Chi}^{2}$ to reject $\mathrm{HO}$, on the contrary, if the statistical significance is $>0.05, \mathrm{HO}$ is not rejected.

\section{DATA ANALYSIS AND INTERPRETATION}

Firstly, from the analysis of the data obtained from the 89 surveyed people, the descriptive results are presented next. We begin with the frequencies for each of the items that made up the questionnaire used in the field test and afterwards, the statistical analysis for the hypothesis test.

From the total of people who participated in the survey: $73 \%$ were female and only $27 \%$ were male, whose ages were the following: between 24 and 29 years old was the highest range with $66.3 \%$, followed by a $23.6 \%$ between the ages of 18 and 23 years old and only $10.1 \%$ was between 30 and 35 years old.

Regarding their current job status, the largest group was made of young people who only work, representing $56.2 \%$ of the surveyed population, $36 \%$ study and work and the minority were young people who only study (7.9\%).

In relation to the concept of saving and the reasons or motives why they save, $30.3 \%$ of the people who were surveyed answered that they will save for retirement, $21.3 \%$ considers it is better to save in order to buy a house or any kind of real state, $20.2 \%$ prefers to save in order to open a business and $11.2 \%$ save for an emergency, while only $3.4 \%$ save money to pay for studies or for traveling.

In the survey by CONSAR (2017) there is an item which inquiries about a phrase people identify with, showing how $74.2 \%$ responded that the most important thing is to prevent and save money, while none of the surveyed identifies with not saving $(0 \%)$.

Concerning the financial capabilities of Millennials, the results of the survey evidence how $53.9 \%$ is used to keep a control of expenses. However, $46.1 \%$ do not do so, suggesting there are still many Millennials who do not keep a record of their expenses. Likewise, in case they received a large amount of money, they would invest it as follows: $38.2 \%$ would spend it to open a business, while $30.3 \%$ would prefer not to spend it and save it and $21.3 \%$ would rather invest in an established business.

On the issue of future forecast, $36 \%$ relates the word "retirement" with pension, while $20.2 \%$ associates it to old age, $16.9 \%$ to rest and $11.2 \%$ to the fact they will not have to work anymore, finally, a $6.7 \%$ relates it to money and saving.

About the topic of retirement, most Millennials (92.1\%) consider retirement to be important. Additionally, $57.3 \%$ of Millennials say they would like to retire before they are 60 years old and the rest of the surveyed would like to retire from 60 years old onwards.

With regard to the options Millennials would choose to sustain themselves during old age, $43 \%$ would choose to have their own business, $16.9 \%$ to have an investment and obtain returns from it and $15.7 \%$ would like to do so with the resources gained from renting properties, those would be the main income sources. Millennials 
also consider the age they must begin to save for retirement to be: for $28.1 \%$ between the ages of 25 to 29 years old, followed by $21.3 \%$ who considers the age to start saving for retirement is between 20 to 24 years old.

On the other hand, $93.3 \%$ of the surveyed answered that it would not be enough to live off a pension of $30 \%$ of their current income. The amount they consider to be adequate for a pension is over $\$ 15000.00 \mathrm{MXN}(31.5 \%)$ followed by a $27 \%$ who consider it should be between $\$ 10001.00$ y $\$ 15000.00$ MXN.

Regarding the retirement funds in the case of Mexico, it can be observed that most Millennials (92.1\%) have knowledge of what they are and $50.6 \%$ consider them to be an additional back-up for old age, while most would make the decision of having a retirement fund $(91 \%)$.

Lastly, the results on saving intention are analyzed, including the reasons or motives that would lead them to save and the way they would do it, where a large percentage of Millennials (91\%) stated their intention of having a retirement fund, which is why table 9 shows the percentage of Millennials willing to save more than $\$ 1000.00$ MXN monthly for their pension (64\%), 21.3\% would save between $\$ 500.00$ and $\$ 1000.00$ MXN and the rest would save between $\$ 100$ and $\$ 490$ or nothing.

Among the reasons why this group of people would save money in a retirement fund, a high percentage stated they would do so because of the returns (62.7\%), while the rest would do so for taxing benefits, promotions and the easy way to use it.

Lastly, Millennials were asked how they would like to be reminded of saving in their retirement fund and the results were the following: $60 \%$ of them, the highest percentage, answered they would prefer if there was an automatic deduction from their payroll, $25.8 \%$ would like to be reminded with notifications to the mobile phone and $5.6 \%$ prefer to remember on their own.

\section{PARAMETRIC RESULTS OF THE HYPOTHESIS TEST}

In order to contrast the established hypothesis, next are described the results obtained from the analysis done using the technique Chi square Pearson test with $d f$ and statistic significance $(<0.05)$ :

\section{Saving}

Null hypothesis: There is no relationship between the concept of saving and gender.

Alternative hypothesis: There is a relationship between the concept of saving and gender.

Table 1. Savings intent

\begin{tabular}{cccc}
\hline Variables & $\begin{array}{c}\text { The most important is to } \\
\text { prevent and save, even } \\
\text { though it is little by little }\end{array}$ & $\begin{array}{c}\text { It is not a lack of } \\
\text { interest; I just do not } \\
\text { have enough to save }\end{array}$ & Total \\
\hline Masculine & $20.2 \%$ & $6.7 \%$ & $27.0 \%$ \\
Feminine & $53.9 \%$ & $19.1 \%$ & $73.0 \%$ \\
Total & $74.2 \%$ & $25.8 \%$ & $100.0 \%$ \\
Pearson's Chi square $(d f 1)$ & & $.012^{\mathrm{a}}$ & \\
Sig. & & .912 & \\
\hline
\end{tabular}

Source: own

As it can be seen in table 1,74.2\% of Millennials consider preventing and saving as the most important, even if it is only possible to save a little money. Also, the table shows the statistic Chi square Pearson ( $d f 1$ ) and its significance; as the value of the significance (.912) is higher than 0.05 , the null hypothesis is not rejected, concluding that there is no relationship between the concept of saving and gender. 


\section{Financial capability} gender.

Null hypothesis: There is no relationship between keeping a record of monthly income and expenses and

Alternative hypothesis: There is a relationship between keeping a record of monthly income and expenses and gender.

Table 2. Record of monthly income and expenses

\begin{tabular}{lccc}
\multicolumn{1}{c}{ Variables } & Record of monthly income and expenses & Total \\
& Yes & No & \\
\hline Masculine & $19.1 \%$ & $7.9 \%$ & $27.0 \%$ \\
Feminine & $34.8 \%$ & $38.2 \%$ & $73.0 \%$ \\
Total & $53.9 \%$ & $46.1 \%$ & $100.0 \%$ \\
Pearson's Chi square $(d f 1)$ & $3.778^{\mathrm{a}}$ & & \\
Sig. & .052 & & \\
\hline
\end{tabular}

Source: own

Table 2 shows that $53.9 \%$ of Millennials keep a record of monthly income and expenses, the rest does not. Also, the table shows the statistic Chi square Pearson ( $d f 1$ ) and its significance; as the value of the significance (.052) is higher than 0.05 , the null hypothesis is not rejected, concluding that there is no relationship between keeping a record of monthly income and expenses and gender.

Null hypothesis: There is no relationship between what Millennials would do if they received an unexpected amount of money and gender.

Alternative hypothesis: There is a relationship between what Millennials would do if they received an unexpected amount of money and gender.

Table 3. Use of a large sum of money

\begin{tabular}{lccccc} 
& Save it & $\begin{array}{c}\text { Set up new } \\
\text { business }\end{array}$ & $\begin{array}{c}\text { Invest in an already } \\
\text { established business }\end{array}$ & Other & Total \\
\hline Masculine & $4.5 \%$ & $10.1 \%$ & $7.9 \%$ & $4.5 \%$ & $27.0 \%$ \\
$\quad$ Feminine & $25.8 \%$ & $28.1 \%$ & $13.5 \%$ & $5.6 \%$ & $73.0 \%$ \\
$\quad$ Total & 30.3 & $38.2 \%$ & $21.3 \%$ & $10.1 \%$ & 100 \\
Pearson's Chi square (df I) & & 4.365 & & \\
Sig. & & .225 & & \\
Source: own &
\end{tabular}

It can be observed in table 3 that $38.2 \%$ of Millennials would set up a new business if the received an unexpected amount of money, while $30.3 \%$ would simply save it and $21.3 \%$ would invest it in an established business.

Also, the table shows the statistic Chi square Pearson ( $d f 1$ ) and its significance; as the value of the significance (.225) is higher than 0.05 , the null hypothesis is not rejected, concluding that there is no relationship between what Millennials would prefer to do if they received an unexpected amount of money and gender.

\section{Future forecast}

Null hypothesis: There is no relationship between what Millennials think when they hear the word retirement and gender.

Alternative hypothesis: There is a relationship between what Millennials think when they hear the word retirement and gender. 


\begin{tabular}{|c|c|c|c|c|c|c|c|}
\hline & $\begin{array}{c}\text { Rest } \\
(\%)\end{array}$ & $\begin{array}{c}\text { Money } \\
(\%)\end{array}$ & $\begin{array}{l}\text { I will not } \\
\text { work } \\
(\%)\end{array}$ & $\begin{array}{c}\text { Pension } \\
(\%)\end{array}$ & $\begin{array}{c}\text { Old age } \\
(\%)\end{array}$ & $\begin{array}{c}\text { Savings } \\
(\%)\end{array}$ & Total \\
\hline Masculine & 6.7 & 2.2 & 3.4 & 6.7 & 6.7 & 1.1 & 27.0 \\
\hline Feminine & 10.1 & 4.5 & 7.9 & 29.2 & 13.5 & 7.9 & 73.0 \\
\hline Total & 16.9 & 6.7 & 11.2 & 36.0 & 20.2 & 9.0 & 100.0 \\
\hline \multicolumn{3}{|c|}{ Pearson's Chi square $(d f 5)$} & 3.782 & & & & \\
\hline & & Sig. & 0.581 & & & & \\
\hline
\end{tabular}

Source: own

Table 4 indicates that $36 \%$ of the surveyed think about pension when they hear the word "retirement" and $20.2 \%$ relate it to old age.

Also, the table shows the statistic Chi square Pearson (df 1 ) and its significance; as the value of the significance (.581) is higher than 0.05 , the null hypothesis is not rejected, concluding that there is no relationship between their opinion on retirement and gender.

Null hypothesis: There is no relationship between receiving a monthly pension and gender.

Alternative hypothesis: There is a relationship between receiving a monthly pension and gender.

Table 5. Monthly pension and gender

\begin{tabular}{lccc}
\hline Variable & Yes (\%) & No (\%) & Total \\
\hline Masculine & 23.6 & 3.4 & 27.0 \\
Feminine & 68.5 & 4.5 & 73.0 \\
Total & 92.1 & 7.9 & 100.0 \\
$\quad$ Pearson's Chi square (df 5) & & .974 & \\
$\quad$ Sig. & & .324 & \\
\hline
\end{tabular}

Source: own

In table 5 , it can be seen that $92.1 \%$ of the population of this study consider that a third $(30 \%)$ of their income is enough to sustain themselves during retirement. Also, the table shows the statistic Chi square Pearson ( $d f 1$ ) and its significance; as the value of the significance (.324) is higher than 0.05 , the null hypothesis is not rejected, concluding that there is no relationship between receiving a monthly allowance as pension and gender.

Null hypothesis: There is no relationship between retirement age and gender.

Alternative hypothesis: There is a relationship between retirement age and gender.

Table 6. Retirement age and gender

\begin{tabular}{lcccc} 
& $\begin{array}{c}\text { Before 60 years old } \\
(\%)\end{array}$ & $\begin{array}{c}\text { From 60 to 64 } \\
\text { years old } \\
(\%)\end{array}$ & $\begin{array}{c}\text { 65 years old or } \\
\text { more } \\
(\%)\end{array}$ & $\begin{array}{c}\text { Total } \\
(\%)\end{array}$ \\
\hline Masculine & 14.6 & 10.1 & 2.2 & 27 \\
Feminine & 42.7 & 21.3 & 9.0 & 73 \\
Total & 57.3 & 31.5 & 11.2 & 100 \\
\multicolumn{2}{c}{ Pearson's Chi square (df 2) } \\
Sig.
\end{tabular}

Source: own

As shown in table $6,57.3 \%$ of Millennials consider that the retirement age should be before 60 years old. Also, the table shows the statistic Chi square Pearson ( $d f 1)$ and its significance; as the value of the significance (.710) is higher than 0.05 , the null hypothesis is not rejected, concluding that there is no relationship between the amount of a pension and gender. 
Null hypothesis: There is no relationship between the age to start saving money and gender. Alternative hypothesis: There is a relationship between the age to start saving money and gender.

Table 7. Saving age and gender

\begin{tabular}{|c|c|c|c|c|c|c|c|}
\hline & $\begin{array}{l}\text { Before } 18 \\
\text { years old } \\
\text { (\%) }\end{array}$ & $\begin{array}{c}\text { From } 18 \\
\text { to } 19 \\
\text { years old } \\
(\%)\end{array}$ & $\begin{array}{c}\text { From } 20 \\
\text { to } 24 \\
\text { years old } \\
(\%)\end{array}$ & $\begin{array}{c}\text { From } 25 \\
\text { to } 29 \\
\text { years old } \\
(\%)\end{array}$ & $\begin{array}{c}\text { From } 30 \\
\text { to } 39 \\
\text { years old } \\
(\%)\end{array}$ & $\begin{array}{c}\text { From } 40 \\
\text { years old } \\
\text { onward } \\
(\%)\end{array}$ & $\begin{array}{c}\text { Total } \\
(\%)\end{array}$ \\
\hline Masculine & 3.4 & 4.5 & 4.5 & 6.7 & 4.5 & 3.4 & 27 \\
\hline Feminine & 13.5 & 15.7 & 16.9 & 21.3 & 5.6 & & 73 \\
\hline \multicolumn{4}{|c|}{$\begin{array}{c}\text { Pearson's Chi square (df 5) } \\
\text { Sig. }\end{array}$} & \multicolumn{4}{|c|}{$\begin{array}{c}10.545 \\
.061 \\
\end{array}$} \\
\hline
\end{tabular}

Source: own

Table 7 shows that $28.1 \%$ of Millennials considered that the age to start saving money is between 25 and 29 years old. Also, the table shows the statistic Chi square Pearson ( $d f 1)$ and its significance; as the value of the significance (.061) is higher than 0.05 , the null hypothesis is not rejected, concluding that there is no relationship between the age to start saving money and gender.

Null hypothesis: There is no relationship between the amount of a pension and gender.

Alternative hypothesis: There is a relationship between the amount of a pension and gender.

Table 8. Pension amount and gender

\begin{tabular}{lcccccc}
\hline & $\begin{array}{c}\text { Up to } \\
\$ 5,000\end{array}$ & $\begin{array}{c}\text { From } \$ 5,001 \\
\text { to } \$ 7,500\end{array}$ & $\begin{array}{c}\text { From } \$ 7,501 \\
\text { to } \$ 10,000\end{array}$ & $\begin{array}{c}\text { From } \$ 10,001 \\
\text { to } \$ 15,000\end{array}$ & $\begin{array}{c}\text { More than } \\
\$ 15,000\end{array}$ & Total \\
\hline Masculine & $2.2 \%$ & $1.1 \%$ & $7.9 \%$ & $4.5 \%$ & $11.2 \%$ & $27.0 \%$ \\
Feminine & $1.1 \%$ & $11.2 \%$ & $18.0 \%$ & $22.5 \%$ & $20.2 \%$ & $73.0 \%$ \\
Total & $3.4 \%$ & $12.4 \%$ & $25.8 \%$ & $27.0 \%$ & $31.5 \%$ & $100.0 \%$ \\
\multicolumn{2}{c}{ Pearson's Chi square (df 5) } & & 6.707 & & \\
\multicolumn{2}{l}{ Sig. } & & & .152 & & \\
\hline
\end{tabular}

Source: own

Table 8 shows that $31.5 \%$ of Millennials consider that the adequate amount of a pension is over $\$ 15000.00$ MXN, 27\% consider it should be between $\$ 10001.00$ and $\$ 15000.00$ MXN and 25.8\% between $\$ 7501.00$ and $\$ 10001.00 \mathrm{MXN}$. Also, the table shows the statistic Chi square Pearson ( $d f 1$ ) and its significance; as the value of the significance (.152) is higher than 0.05 , the null hypothesis is not rejected, concluding that there is no relationship between the amount of a pension and gender.

\section{Retirement fund}

Null hypothesis: There is no relationship between the knowledge about a retirement fund and gender.

Alternative hypothesis: There is a relationship between the knowledge about a retirement fund and gender. 


\begin{tabular}{|c|c|c|c|c|c|c|}
\hline & $\begin{array}{l}\text { Up to } \\
\$ 5,000\end{array}$ & $\begin{array}{c}\text { From } \$ 5,001 \\
\text { to } \$ 7,500\end{array}$ & $\begin{array}{c}\text { From } \$ 7,501 \\
\text { to } \$ 10,000\end{array}$ & $\begin{array}{c}\text { From } \$ 10,001 \\
\text { to } \$ 15,000\end{array}$ & $\begin{array}{c}\text { More than } \\
\$ 15,000\end{array}$ & Total \\
\hline Masculine & $2.2 \%$ & $1.1 \%$ & $7.9 \%$ & $4.5 \%$ & $11.2 \%$ & $27.0 \%$ \\
\hline Feminine & $1.1 \%$ & $11.2 \%$ & $18.0 \%$ & $22.5 \%$ & $20.2 \%$ & $73.0 \%$ \\
\hline Total & $3.4 \%$ & $12.4 \%$ & $25.8 \%$ & $27.0 \%$ & $31.5 \%$ & $100.0 \%$ \\
\hline \multicolumn{3}{|c|}{ Pearson's Chi square ( $d f$ 5) } & & $\begin{array}{c}6.707 \\
152\end{array}$ & & \\
\hline
\end{tabular}

Source: own

Table 9 indicates that $92.1 \%$ of them have knowledge about what a retirement fund is, while it also shows Pearson s Chi-square statistic ( $d f$ ) and its significance; since the significance value (.431) is higher than 0.05 , the null hypothesis is not rejected, concluding there is no relationship between knowledge about a retirement fund and gender.

\section{DISCUSSION AND CONCLUSIONS}

The aim of this study was knowing the relationship between Savings, Financial Capability, Future forecast and Retirement fund with gender, allowing to determine the savings culture while proving if there is a relation between Savings, Financial Capability, Future forecast and Retirement fund with gender in the population called millennial generation. To achieve this end, the survey created by the Mexican National Commission of Retirement Savings System was used.

The result of the descriptive analysis shows how, generally, a high percentage of surveyed young people consider it to be important to prevent and save money, even if it is a small amount. Nonetheless, among the reasons why Millennials decide to save money, retirement is not the main reason motivating them, as there were more people who voted for other options. Only $30 \%$ of the population chose this option, meaning that $70 \%$ of people does not consider retirement to be a priority in the case they decide to save money. These others would prefer to save for other things, such as buying a property, setting up a business or for some emergency.

On the other hand, even if it is possible to observe a little more financial culture in this generation, there are still many Millennials who do not keep a record of monthly expenses, which is why, by not keeping control of their finances, possibly they do not have spare money to save. However, even though they are more aware and see saving money as an important issue, if this group of people received a considerable amount of money, they would rather use it to invest in a business than save it.

Concerning the parametric results, according to the $\mathrm{Chi}^{2}$ analysis, there is no relationship between the concept of savings and gender. Similarly, there is no evidence of the relationship between what Millennials perceive about recording the monthly income and expenses with gender. Regarding what Millennials would do in case they received a large sum of money, $38.2 \%$ would set up a new business, but was the significance value is higher than 0.05 , the null hypothesis is not rejected, concluding there is no relation between what Millennials prefer to do if they received an unexpected amount of money and gender.

Likewise, in relation to pensions, there is no evidence of a relationship between receiving a monthly pension and gender, neither is there a relationship between retirement age and gender. Regarding the amount of pension to retire, according to the opinion of the surveyed Millennials, no evidence was found to prove the relation between the pension amount and gender. Finally, on the issue of retirement funds, there is evidence to sustain there is no relation between the knowledge of what a retirement fund is and gender.

These results match other studies, like the survey by Mexican National Commission of Retirement Savings System (2017), whose results indicate that despite the interest shown by Millennials in saving money, their Future forecast does not reflect in concrete actions, as only $20 \%$ thinks about saving money for retirement. Along those 
lines, the study by BANAMEX-UNAM (National Bank of Mexico and National Autonomous University of Mexico) (2014) found that $61 \%$ has not thought about saving for old age.

Ultimately, even though Millennials associate the word "retirement" with pension and they consider it to be important; many of them do not plan to live off it. They would prefer to sustain themselves in old age with a business, investments or renting real state, since for them a pension of 30\% of income, which is the current replacement rate, would not be enough to live by. They think pensions should be over $\$ 15000.00 \mathrm{MXN}$.

Likewise, they know what a retirement fund is and consider it to be an additional back-up for old age, which is the why they would not live by only with the pension. Also, they consider that if they opened a retirement fund account, they would like to contribute more than $\$ 100.00 \mathrm{MXN}$ each month, amount that should be discounted from the payroll and the reason they would have a retirement fund account is because of the returns, while others would do it for the taxing benefits.

In conclusion, we could say that the Millennial generation is aware of the importance of saving. Unfortunately, despite this and the fact they are aware about the current replacement rate not being enough to live by in old age, they are not saving for retirement and prefer to save for other reasons, something that should not happen because, as stated by Bams, Schotman \& Tyagi (2016), the OECD (2016), Rivera \& Nava (2012) and Vázquez (2010), the pension system nowadays is not favorable and so, if they do not save for retirement, they will not be able to attain a worthy pension and their future will be affected because of poor decisions made in the present.

Considering the results obtained in the present study and by having analyzed the perception of Millennials towards retirement savings, it was concluded that they do not place importance on retirement and only see retirement funds as an additional source of income to live by during old age; it is expected that in future studies, researchers show alternative models and new strategies to catch the attention of this group of young people, in order for them to acquire more interest towards this subject, so they do not lose their future.

\section{BIBLIOGRAPHIC REFERENCES}

Alvarado-Lagunas, E., \& Duana-Ávila, D. (2018). Ahorro, retiro y pensiones: ¿Qué piensan los jóvenes adolescentes del ahorro para el retiro? Investigación Administrativa, 48(122)

Bams, D., Schotman, P., \& Tyagi, M. (2016). Pension fund asset allocation in low interest rate environment. https://bit.ly/3iGnVBg.

Banco del Ahorro Nacional y Servicios Financieros (Financial Services and National Savings Bank) (BANSEFI) (2015). Diagnóstico programa presupuestario en la inclusión financiera. https://bit.ly/2PXq201.

Banco Nacional de México (BANAMEX) y Universidad Nacional Autónoma de México (UNAM) (National Bank of Mexico and National Autonomous University of Mexico) (2014). Cultura financiera de los jóvenes en México. Síntesis de resultados. https://bit.ly/31X29m5.

Berhneim, D. (1993). Is the Baby Boom Generation Preparing Adequately for Retirement? Summary report. Princeton: Merrill Lynch.

Calderón-Ortiz, A. \& Gaytán-Cortés, J. (2017). El Valor del Conocimiento y Efectos en la Competitividad. https://bit.ly/2Y549HG.

Cámara de Diputados (Chamber of Representatives). (January 10, 2014). Article 18. Ley de los Sistemas de Ahorro para el Retiro (Retirement Savings Systems Law). [Law 077 of 2014]. D0: 10/01/2014.

Comisión Nacional del Sistema de Ahorro para el Retiro (National Commission of te Retirement Savings System) (CONSAR). (2017). Encuesta Nacional ¿Qué piensan los millennials mexicanos del ahorro para el retiro? https://bit.ly/3axINc5.

Escalera-Chávez, M., Tejada-Peña, E., \& García-Santillán, A. (2017). Uso de los servicios financieros. Estudio empírico en estudiantes universitarios. International Journal of Developmental and Educational Psychology, 2(1), 581-590.

Finke, M. \& S. Huston. (2013). Time preference and the importance of saving for retirement. Journal of Economic Behavior \& Organization, 89, 23-34. 
García, N., Grifoni, A., López, J., \& Mejía, D. (2013). La educación financiera en América Latina y el Caribe. Situación actual y perspectivas. Serie Políticas Públicas y Transformación Productiva, 12. http://scioteca.caf.com/handle/123456789/379

Goldman Sachs. (2016). Investing in the Millennial Effect. https://bit.ly/312iQNR.

Heman Hasbach, D. (2017). ¿Podrán los Millennials cobrar pensión?: Una aplicación al caso de México. (Tesis del Máster en Dirección de Entidades Aseguradoras y Financieras, Universidad de Barcelona) https://bit.ly/3gXUmL7.

Keynes, J. (1936). The General Theory of Employment, Interest and Money. New York: Harcourt and Brace.

Huidobro, A. (1995). La importancia del Ahorro en la Economía. https://bit.ly/340w600.

Instituto Nacional de Estadística y Geografía (National Institute of Statistic and Geography) (INEGI). (2015). Encuesta intercensal 2015. https://www.inegi.org.mx/temas/estructura/

Johnson, S. (2016). Los asiáticos ahorran, Ios latinos gastan. Financial times, 8-9.

Organización para la Cooperación y el Desarrollo Económicos (Organization for Economic Cooperation and Development) (2016). Estudios de la OCDE s obre los sistemas de pensiones: México. https://bit.ly/3h4qBZd.

Rivera, J., \& Nava, A. (2012). El sistema de ahorro para el retiro y la cultura de la previsión en México. Ciencia UANL, 15(57), 33-38.

Rolison, J., \& Hanoch \& S. Wood. (2017). Saving for the future: Dynamic effects of time horizon. Journal of Behavioral and Experimental Economics, 70, 47-54.

Vázquez-Parra, J., Montalvo-Corzo, R., Amézquita-Zamora, J., \& Arredondo-Trapero, F. (2017). El ahorro en la carencia. Una reflexión sobre los hábitos de ahorro de familias de una zona vulnerable de México. Perspectivas, (39), 103-120.

Vázquez, P. (2010). Las pensiones en México y su problemática. (Ponencia presentada a los alumnos de la maestría en Finanzas del ITESM, Campus Monterrey). http://millenium.itesm.mx/

Villagómez, A., (1993). Los determinantes del ahorro en México: una reseña de la investigación empírica. Economía Mexicana Nueva Época, (2), 305-327.

Wealth Planter. (2017). ¿En qué gastan su dinero los jóvenes? http://www.wplanters.com/en-que-gastan-sudinero-los-jovenes/

Yao, R. \& G. Cheng. (2017). Millennial s retirement saving behavior: Account ownership and balance. Family and Consumer Sciences Research Journal, 46(2), 110-128.

Zamora-Lobato, T., García-Santillán, A., \& Ramos-Hernández, J. (2018). Algunas características que explican el comportamiento de los jóvenes universitarios hacia el ahorro. International journal of developmental and educational psychology, (2), 159-170. 


\begin{abstract}
Annex
Survey on the retirement savings culture of millennials

Dear participant:

The aim of this survey is to gather information that will be used to know what is the perception of young people on retirement savings and how much they know about this issue. The information provided in this survey is strictly confidential and will only be used for research purposes. Because of the former, we request your valuable collaboration to answer some questions, which will not take much time. In advance, we reiterate our gratitude and ratify that this data will be treated at all times with the outmost confidentiality and anonymity to protect the identity of the participant.
\end{abstract}

Thank you for your support

Section I Demographic Data

Age:

Gender: Masculine ( ) Feminine ( )

Current job status: Just study ( ) Study and work ( ) Work ( )

Instructions: Answer the following questions by choosing the option you consider convenient according to the scale presented next. Do not leave any question unanswered.

\title{
Section II
}

Saving concept

1. Thinking in the long term, what would be your main reason / motivation to save money?

- For an emergency

- To buy an estate / house / apartment

- Set up a business

- Prepare for retirement

- Travel / Holidays

- Investment

- Buy a car / motorbike

- Buy an asset (clothes, accessories, phone)

- Pay for school

2. Of the following phrases, with which do you identify the most?

- The most important is to prevent and save, even though it is little by little

- It is not a lack of interest, I just do not have enough to save

- Why save, I prefer to spend it now

\section{Financial capability}

3. Do you regularly maintain a record of your monthly income and expenses?

- Yes

- No

4. If you unexpectedly receive a large amount of money, what would you rather do with it?

- Save it

- Set up a new business

- Invest in an already stablished business

- Other. Mention which 


\section{Future forecast / Pension}

5. Of the following words, what is the first thing that comes to mind when hearing the word RETIREMENT?

- Rest

- Money

- That I will not work

- Pension

- Old age

- Savings

6. Is it important to you to retire and receive a pension?

- Yes

- No

7. At what age would you be interested in retiring and receive a pension?

- Before 60 years old

- From 60 to 65 years old

- 65 years old or more

8. What do you plan to do to support yourself financially during old age?

- Save money

- A business

- Keep working

- Retirement pension

- Invest

- Rent real estate

- Live off my estates

9. At what age do you think a person needs to begin to save in order to have a good pension?

- Before 18 years old

- From 18 to 19 years old

- From 20 to 24 years old

- From 25 to 29 years old

- From 30 to 39 years old

- From 40 years old onwards

10. If you were told you would receive a monthly pension equal to a third (30\%) of what you earn today, do you consider it would be enough to support yourself during retirement?

- Yes

- No

11. Which amount do you consider to be a proper pension?

- Up to $\$ 5,000 \mathrm{MXN}$

- From $\$ 5,001$ to $\$ 7,500 \mathrm{MXN}$

- From $\$ 7,501$ to $\$ 10,000 \mathrm{MXN}$

- From $\$ 10,001$ to $\$ 15,000 \mathrm{MXN}$

- More than $\$ 15,000 \mathrm{MXN}$

\section{Retirement funds}

12. Do you know what an retirement fund is?

- Yes

- No

13. What means to you the savings you have in the retirement fund account?

- The only source of income for old age

- An additional back-up for old age

- An insufficient back-up for old age 
14. Would you like to have a retirement fund and save for retirement?

- Yes

- No

15. In the retirement funds you can save and multiply your money for retirement, how much would you be willing to save monthly?

- More than $\$ 100$ pesos

- Between $\$ 50$ and $\$ 100$ pesos

- Between $\$ 10$ and $\$ 49$ pesos

- Nothing

16. What would motivate you the most to save in a retirement fund account?

- The profits /returns

- That it is easy to do so

- Retirement fund promotions

- Deductibility / tax benefits

17. If you decided to start saving money today or increase your retirement savings a little, what would you prefer?

- That your retirement fund reminds you each month to make a deposit/transfer through a text message

- That the amount is automatically deducted and transferred from your payroll account or your debit card.

- Remember yourself each month and make the deposit/transfer

Thank you for your invaluable support 
